


\title{
METHODS OF COMBATING FUNGUS DISEASE ON FISHES
} IN CAPTIVITY

\section{$*$}

\author{
By. Charles F. Holder
}

Paper presented before the Fourth International Fishery Congress held at Washirgton, U. S. A., September 22 to 26, 1908

BULLETIN OF THE BUREAU OF FISHERIES : : : : : : VOL. XXVIII, P. 933.936

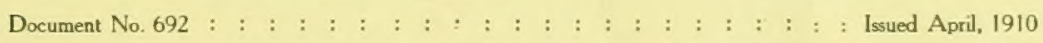

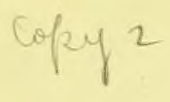




$$
\text { का से से की }
$$

APR 151910

7. OP $\mathrm{AS}$

$\because \vdots \vdots$ 


\title{
METHODS OF COMBATING FUNGUS DISEASE ON FISHES IN CAPTIVITY.
}

\author{
$*$ \\ BY CHARLES F. HOLDER.
}

The few suggestions made in this connection are the result of observations made in several tank aquariums and a series of open-reef aquariums on the Florida coast for the study of corals and fishes.

Fishes in confinement are subject to fungus disease in a ratio as the conditions under which they are kept differ from those of their normal habitat. Such differences vary largely with the intelligence or ignorance of the keepers, or their carelessness. Fishes are handled improperly, have been injured previously or in their capture; they are overfed and food collects in the tanks; aeration is incomplete; there is an overabundance of algæ; or the cement of the tank may be poisonous. All these factors are causes of disease, as I observed in the New York Aquarium in 1873, in the Santa Catalina Zoological Station in I903-I908, and in Florida where aquariums were built out into the reef.

It has been my experience, then, that if preventive measures are sufficient few fish are diseased or lost, and the point of my suggestions relating to fungus affecting a species of fish under cultivation is that the Chinese method of materia medica should be adopted-namely, not to cure but to keep well. A set of rules bearing on the prevention of disease should be observed by every aquarium attendant. Such rules are as follows:

I. Never take out fish with the bare hands. Lift them carefully with a large fine-mesh net. Under no circumstances touch them, as handling often produces fungus.

II. Give the fish proper and natural aeration. "The surf or near-shore fishes require more or direct aeration; deep water forms require less.

III. Never allow food to collect in the tank. Have every tank supplied with an abundance of natural scavengers - crabs of various kinds, barnacles (sea water). In fact, it should be the most important qualification of an attendant to know how to equip a tank to give the fish natural surroundings. The habits of the fish should be known, its usual food given it, and the balance should be preserved in the tanks, each being supplied, so far as possible, with the conditions found in natural life.

The following are some experiments successfully tried at the Avalon Zoological Station. 
I. Fungus growth developed on sculpins. Investigation showed that there were 50 per cent too many in the tank. The fish, a near-shore, rocky-bottom species, needed maximum aeration; this was increased and in a few weeks the fishes were in the best of condition.

2. Male sheepshead constantly died because attacked with a virulent fungus; swam at the surface with the head out of water; showed bruises over body, and lacerated fins. Attendant diagnosed the case as "fish sickness." The habits of the fish were carefully studied, a man watching them even at night. This watcher reported that as soon as the lights went out the largest males attacked the other males furiously and repeatedly bit and lacerated them. The next day two sheepshead tanks were arranged, each with one male to ten or twelve females. In these there was no more difficulty with fungus growth.

3. Surf-fish were attacked with malignant fungus growth. They were in a tank with air coming up through the bottom, thus receiving the minimum amount of aeration. The surf-fish in California lives near the surf and requires the rush of well aerated water. Surface aeration of a violent kind was provided and the fishes recovered at once.

4. A mysterious illness attacked rock bass. Examination of the tank showed poor sanitary conditions. The fish were invariably overfed, the débris collected at the bottom, and the underside of the rocks was covered with "white." Feeding was stopped for several days, a larger per cent of salt introduced, and scavengers-hermit crabs, mollusks of various kinds-were put into the tank. In two weeks the tanks were completely sanitary.

5. Fish in a standing tank were troubled with fungus growth. It was suspected that the evaporation (near sunlight) was too rapid, and fresh water was added, a quart at a time. The fishes recovered, apparently showing the trouble to be too much salt.

Briefly, I would advocate, instead of elaborate and expensive treatment of fishes, prevention; in other words, a study of the habits of fishes, so that each one kept in confinement may be given the conditions and environment it requires. If this is done, at least in my experience it has so proved, fungus disease need not be dreaded, as it will not appear.

As to treatment for fungus, however, if the fish is a common one and easily replaced, as trout, remove and destroy it at once and waste no time on it. If the fish is rare and treatment is necessary, remove it to a new tried tank and double or quadruple the aeration from overhead or direct fall. See that the tank has scavengers (crabs) sufficient to keep it perfectly pure and clean. If fungus has developed, take the fish out, using gloves, and wipe the spots with a sponge dipped in a strong solution of salt and water. Stop feeding for a few days; then give the fish its natural food, if this can be determined. 


\title{
METHODS OF COMBATING FUNGUS DISEASE ON FISHES IN CAPTIVITY \\ $\star$
}

\author{
By Charles F. Holder
}

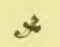

Paper presented before the Fourth International Fishery Congress

held at Washirgton, U. S. A., September 22 to 26, 1908

BULLETIN OF THE BUREAU OF FISHERIES : : : : : : VOL. XXVIII, P. 933.936

Document No. 692 : : : : : : : : : : : : : : : : : : : : : : Issued April, 1910 


$$
544^{14}+1
$$




\title{
METHODS OF COMBATING FUNGUS DISEASE ON FISHES IN CAPTIVITY.
}

\author{
* \\ By CHARLES F. HOLDER.
}

The few suggestions made in this connection are the result of observations made in several tank aquariums and a series of open-reef aquariums on the Florida coast for the study of corals and fishes.

Fishes in confinement are subject to fungus disease in a ratio as the conditions under which they are kept differ from those of their normal habitat. Such differences vary largely with the intelligence or ignorance of the keepers, or their carelessness. Fishes are handled improperly, have been injured previously or in their capture; they are overfed and food collects in the tanks; aeration is incomplete; there is an overabundance of algæ; or the cement of the tank may be poisonous. All these factors are causes of disease, as I observed in the New York Aquarium in 1873, in the Santa Catalina Zoological Station in 1903-I908, and in Florida where aquariums were built out into the reef.

It has been my experience, then, that if preventive measures are sufficient few fish are diseased or lost, and the point of my suggestions relating to fungus affecting a species of fish under cultivation is that the Chinese method of materia medica should be adopted-namely, not to cure but to keep well. A set of rules bearing on the prevention of disease should be observed by every aquarium attendant. Such rules are as follows:

I. Never take out fish with the bare hands. Lift them carefully with a large fine-mesh net. Under no circumstances touch them, as handling often produces fungus.

II. Give the fish proper and natural aeration. The surf or near-shore fishes require more or direct aeration; deep water forms require less.

III. Never allow food to collect in the tank. Have every tank supplied with an abundance of natural scavengers-crabs of various kinds, barnacles (sea water). In fact, it should be the most important qualification of an attendant to know how to equip a tank to give the fish natural surroundings. The habits of the fish should be known, its usual food given it, and the balance should be preserved in the tanks, each being supplied, so far as possible, with the conditions found in natural life.

The following are some experiments successfully tried at the Avalon Zoological Station. 
I. Fungus growth developed on sculpins. Investigation showed that there were 50 per cent too many in the tank. The fish, a near-shore, rocky-bottom species, needed maximum aeration; this was increased and in a few weeks the fishes were in the best of condition.

2. Male sheepshead constantly died because attacked with a virulent fungus; swam at the surface with the head out of water; showed bruises over body, and lacerated fins. Attendant diagnosed the case as "fish sickness." The habits of the fish were carefully studied, a man watching them even at night. This watcher reported that as soon as the lights went out the largest males attacked the other males furiously and repeatedly bit and lacerated them. The next day two sheepshead tanks were arranged, each with one male to ten or twelve females. In these there was no more difficulty with fungus growth.

3. Surf-fish were attacked with malignant fungus growth. They were in a tank with air coming up through the bottom, thus receiving the minimum amount of aeration. The surf-fish in California lives near the surf and requires the rush of well aerated water. Surface aeration of a violent kind was provided and the fishes recovered at once.

4. A mysterious illness attacked rock bass. Examination of the tank showed poor sanitary conditions. The fish were invariably overfed, the débris collected at the bottom, and the underside of the rocks was covered with "white." Feeding was stopped for several days, a larger per cent of salt introduced, and scavengers-hermit crabs, mollusks of various kinds-were put into the tank. In two weeks the tanks were completely sanitary.

5. Fish in a standing tank were troubled with fungus growth. It was suspected that the evaporation (near sunlight) was too rapid, and fresh water was added, a quart at a time. The fishes recovered, apparently showing the trouble to be too much salt.

Briefly, I would advocate, instead of elaborate and expensive treatment of fishes, prevention; in other words, a study of the habits of fishes, so that each one kept in confinement may be given the conditions and environment it requires. If this is done, at least in my experience it has so proved, fungus disease need not be dreaded, as it will not appear.

As to treatment for fungus, however, if the fish is a common one and easily replaced, as trout, remove and destroy it at once and waste no time on it. If the fish is rare and treatment is necessary, remove it to a new tried tank and double or quadruple the aeration from overhead or direct fall. See that the tank has scavengers (crabs) sufficient to keep it perfectly pure and clean. If fungus has developed, take the fish out, using gloves, and wipe the spots with a sponge dipped in a strong solution of salt and water. Stop feeding for a few days; then give the fish its natural food, if this can be determined. 
